\section{International Scientific Journal Theoretical \& Applied Science}

p-ISSN: 2308-4944 (print) e-ISSN: 2409-0085 (online)

Year: 2017 Issue: 09 Volume: 53

Published: 22.09.2017 http://T-Science.org
Olga Vladimirovna Volichenko candidate of architecture, associate professor Kyrgyz-Russian Slavic University (KRSU) wolitschenko@mail.ru

Ravil Munirovich Muksinov doctor of architecture, professor Kyrgyz-Russian Slavic University (KRSU)

SECTION 8. Architecture and construction.

\title{
TECHNICISM CONCEPTS IN ARCHITECTURE CENTRAL ASIA
}

Abstract: The article deals with the formation and development of the architecture of high-tech and new conceptual trends prevailing in the twenty-first century on the territory of Central Asia.

Key words: architecture, concepts, technicism, modernism, high-tech, atectonic shells, megastructuralism, cybertexture.

Language: Russian

Citation: Volichenko OV, Muksinov RM (2017) TECHNICISM CONCEPTS IN ARCHITECTURE CENTRAL ASIA. ISJ Theoretical \& Applied Science, 09 (53): 132-139.

Soi: http://s-o-i.org/1.1/TAS-09-53-20 Doi: crossef https://dx.doi.org/10.15863/TAS.2017.09.53.20

\section{КОНЦЕПЦИИ ТЕХНИЦИЗМА В АРХИТЕКТУРЕ ЦЕНТРАЛЬНОЙ АЗИИ}

Аннотация: В статье рассматривается становление и развитие архитектуры хай-тека и новые концептуальные направления, сложившиеся в ХХІ веке на территории Центральной Азии.

Ключевые слова: архитектура, концепции, техницизм, модернизм, хай-тек, атектоничные оболочки, мегаструктурализм, кибертектура.

\section{Введение}

В начале XXI века, новейшие технологии определяют сущность, содержание и уровень нашей жизни. Модернистский стиль в архитектуре, так называемый хай-тек или техницизм, как известно, возник в семидесятые годы и за свою сороколетнюю историю получил наибольшее распространение по всему миру, по сравнению с другими архитектурными направлениями. Поступательное движение хайтека в новейшее время очевидно. В следствии широкой экспансии идей хай-тека в архитектуре происходит внутри профессиональная рефлексия отпочковываются различные идеи формообразования и больше дифферинцируется образно-стилевая манера.

Хай-тек - это модификация техницизма, выступающего за коренную инновацию архитектурного языка под воздействием научнотехнического прогресса. Концепция хай-тека, по сути, является символическим изображением $\mathrm{XX}$ века - века ракетно-космических объектов, «высоких технологий», масштабных инженернотехнических сооружений, максимально техницизированных общественных зданий. Хайтек явился логическим продолжением радикального дизайна в архитектуре, он стал олицетворением эксклюзивных идей, новых

ISPC Innovations in science,

Philadelphia, USA технологий и строительных материалов, таких как пластик, сталь, хром, стеклянные волокна и т.п. Родоначальником хай-тека считают Бакминстера Фуллера, создателя пространственных сетчатых структур из стальных стержней, т.н. «геодезических куполов» [1]. Теоретическое обоснование концепция хайтека впервые получила в разработках английской группы «Archigram» [2]. Концептуальный и художественно-эстетический образ будущей архитектуры хай-тека еще в 30-е годы XX века был дан в рисунках советского архитектора Якова Чернихова. Он в многочисленных изображениях представил новую архитектуру зданий и сооружений, в которых несущие металлические опоры сочетались со строгими плоскостями ограждающих конструкций и элементами инженерного оборудования [3]. Хайтек стал следующим этапом освоения новых машинообразных, технических форм, который был начат конструктивизмом и функционализмом 20-х гг., затем продолжен в архитектуре минимализма и структурализма 60-х годов.

Говоря об истории развития архитектуры хай-тека можно сделать вывод, что она насчитывает три этапа: 1 этап - с конца 60-х до конца 70-х годов - соединение искусства и тех- 
ники; 2 этап - с начала 80-х до конца 90-х годов - этап развертывания потенциала. Равноправное, полноценное самостоятельное течение, системное явление (заимствование техники для улучшения архитектурных качеств объекта); 3 этап - с начала 2000 г. - этап качественного переосмысления.

\section{Качественное}

переосмысления деятельности и результатов технической революции в авангардной архитектуре.

В технологическом плане это не заимствование, а специальная разработка техники на самом высоком уровне вплоть до использования космических технологий. С другой стороны приравнивание архитектурного сооружения к техническому агрегату, т.е. не его имитация, а полное воспроизведение. Зданиеагрегат вырабатывает электроэнергию, тепло, очищает воздух и т.п. Архитекторы, работающие в области архитектурного техницизма, гибко сочетают язык техники с языком пластического искусства.

Так, новую архитектуру поверхности, созданную по законам неевклидовой геометрии, имманентными качествами которой является легкость, невесомость, обтекаемость и мягкость форм демонстрирует концепция «атектоничные оболочки» [4]. В качестве примера воплощения этой концепции можно привести проект новой Национальной библиотеки в Астане, разработанный датским бюро «BIG» (рис.1). Основу формообразования объекта составляет гигантская трехмерная лента Мебиуса, плавные очертания которой, как это не парадоксально напоминают образ юрты. Конечно, это не буквальное повторение всем знакомого облика юрты, но её архетип очевиден. Эффект усиливается внешним декоративным оформлением здания библиотеки, в виде решеток кёреге.

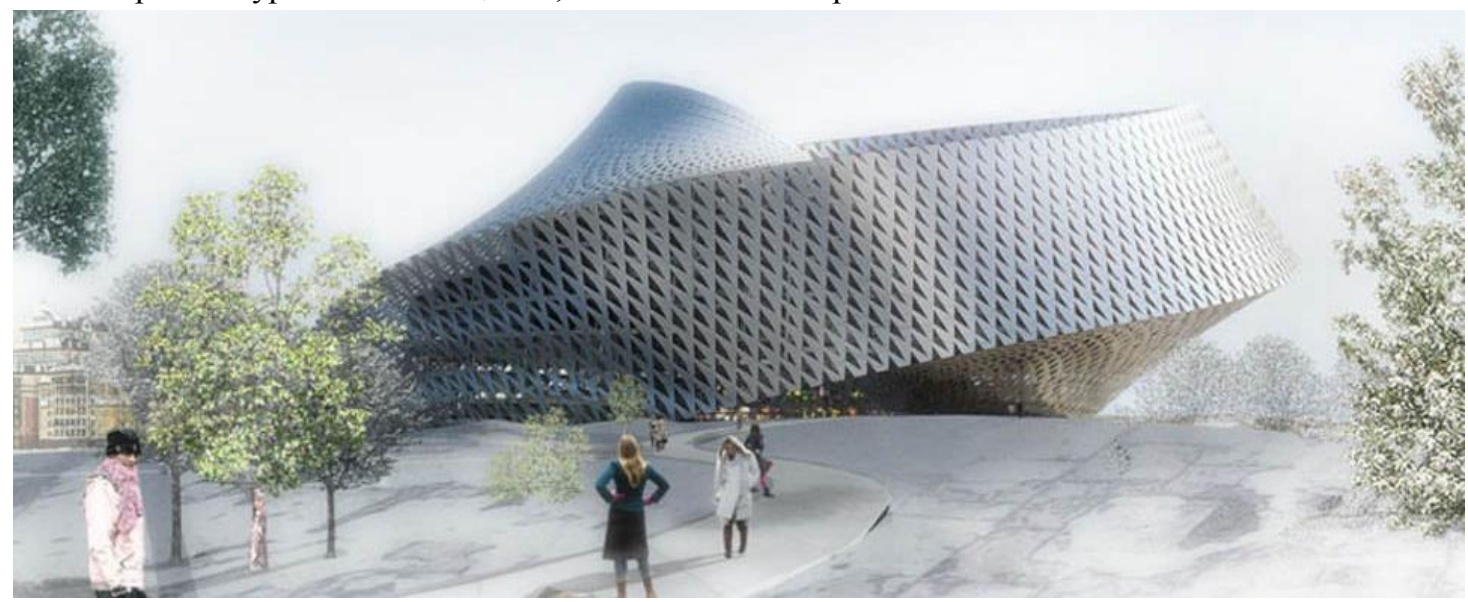

Рисунок 1 - Астана. Проект Национальной библиотеки, архитектурное бюро «BIG»,

Режим доступа: http://spectr.com.kz/category/kultura/biblioteka-pervogo-prezidenta-lidera-natsii-simvoliziruetzhiznennuyu-silu-sovremennogo-kazakhstana.html

Другой пример, проект нового железнодорожного вокзала в Астане (рис. 2) от архитектурной мастерской «Студия 44» петербургского архитектора Н. Явейна. Самой зрелищной составляющей этого проекта стала арка - прозрачная структура в виде гиперболического параболоида, рисунок покрытия которой воспроизводит в гигантском масштабе решетчатую структуру кёреге [5].

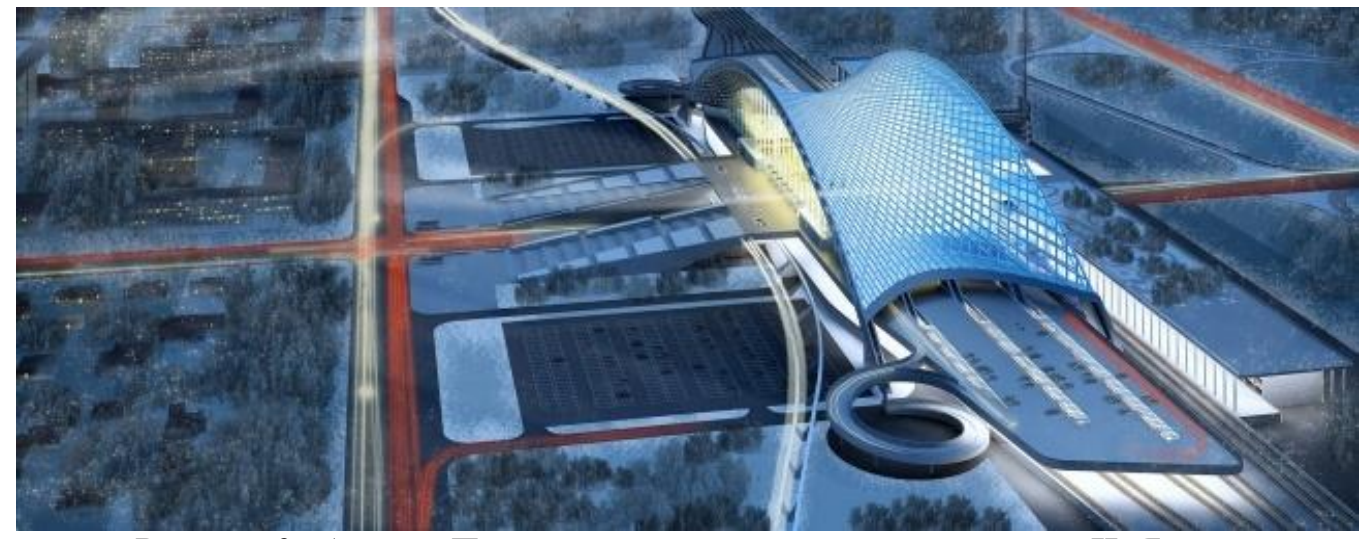

Рисунок 2 - Астана. Проект железнодорожного вокзала, арх. Н. Явейн.

Режим доступа: http://archi.ru/projects/world/6938/zheleznodorozhnyi-vokzal-v-astane

ISPC Innovations in science,

Philadelphia, USA 
Международный конкурс на разработку проекта выставочного комплекса «ЭКСПО-17» на тему «Энергия будущего» в Астане, в котором приняли участие самые известные архитекторы и архитектурные студии с мировым именем, несомненно оказал огромное влияние на развитие архитектуры всего центральноазиатского региона. Конкурсные архитектурные проекты предоставили множество разнообразных примеров внедрения новейших инновационных технологий и разработок, минимизирующих отрицательное воздействие на окружающую среду, использующих замкнутые циклы энерго- и ресурсопотребления, альтернативные природные источники энергии и т.п. Например, проект выставочного комплекса «ЭКСПО-17» Манфреди Николетти вошел в десятку лучших. Идея комплекса сочетает такие природные явления как облака, ветер и цветы. Огромное пространство комплекса все перекрыто огромной оболочкой в виде опустившегося на землю облака, вздымающаяся поверхность которого сплошь покрыта солнечными батареями. Под этой оболочкой разместятся все выставочные павильоны и необходимая инфраструктура. Символ комплекса выполнен в виде башни «Желгул» - (жел - ветер, гул - цветок). Центральный «стебель» башни облицован белым маовым стеклом, которое становится прозрачным в области «бутона», где располагаются несколько уровней смотровых площадок. В вертикальной поверхности башни предусматривались отверстия для снижения ветрового воздействия, в которых располагаются ветровые турбины, превращая «Желгул» в огромный ветровой генератор (рис. 3).

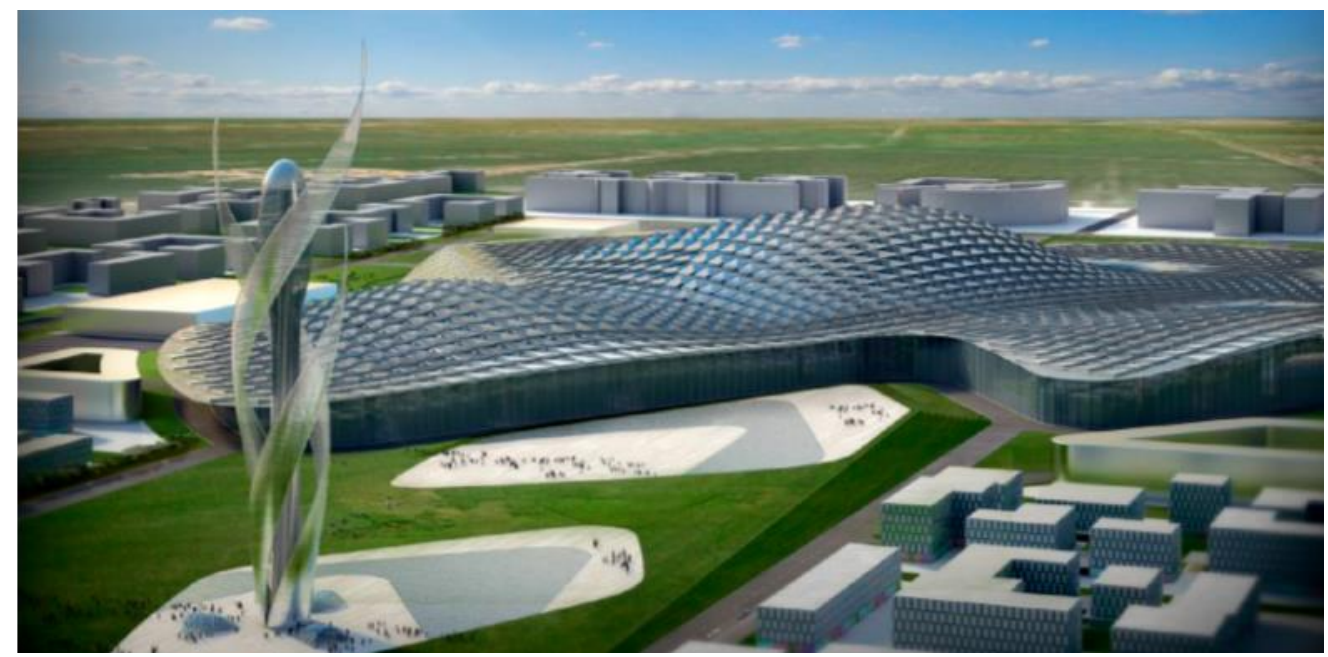

Рисунок 3 - Астана. Проект выставочного комплекса «ЭКСПО-17», арх. М. Николетти. Режим доступа: http://yvision.kz/post/370009

Наиболее популярным и модным направлением в архитектуре на сегодняшний день становится «мегаструктурализм». ОН обосновывает динамическое изменение здания, опровергая традиционную статичность, присущую архитектуре [6]. Перемещение осуществляет благодаря повороту этажей здания вокруг неподвижной оси. К архитектуре «мегаструктурализма» в какой-то мере можно отнести жилой комплекс «Изумрудный» в Астане, который состоит из двух вытянутых корпусов неправильной формы, образованных девятью нестандартными блок-секциями. Сложный силуэт и разнообразное размещение блок секций на участке создает ощущение свободы и живопис ной непринужденности комплекса. 


\begin{tabular}{l|lrl|l|ll} 
& ISRA (India) & $=\mathbf{1 . 3 4 4}$ & SIS (USA) & $=\mathbf{0 . 9 1 2}$ & ICV (Poland) & $=\mathbf{6 . 6 3 0}$ \\
Impact Factor: & ISI (Dubai, UAE) $=\mathbf{0 . 8 2 9}$ & PUHU (Russia) $=\mathbf{0 . 2 0 7}$ & PIF (India) & $=\mathbf{1 . 9 4 0}$ \\
& GIF (Australia) & $\mathbf{0 . 5 6 4}$ & ESJI (KZ) & $=\mathbf{3 . 8 6 0}$ & IBI (India) & $\mathbf{4 . 2 6 0}$
\end{tabular}

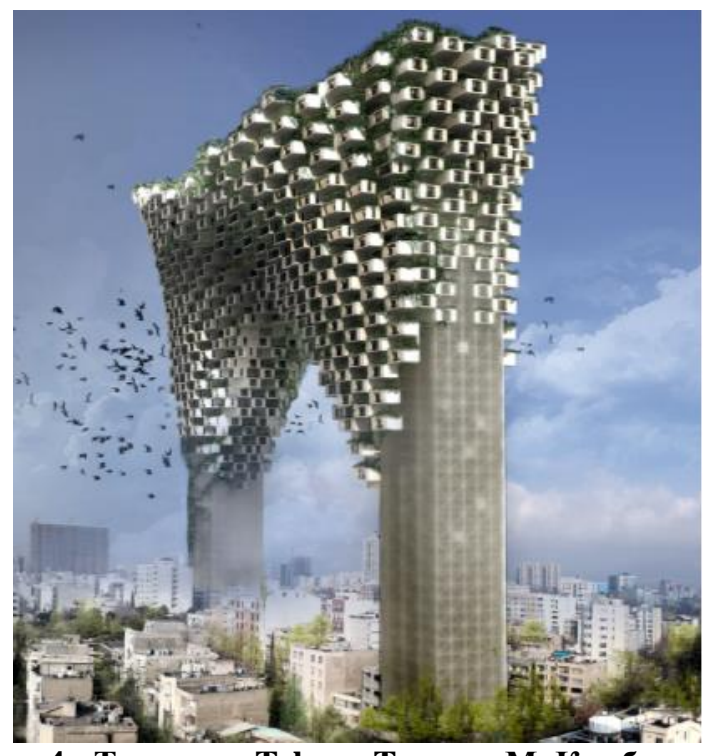

Рисунок 4 - Тегеран. «Tehran Tower», М. Камбоозия и др.

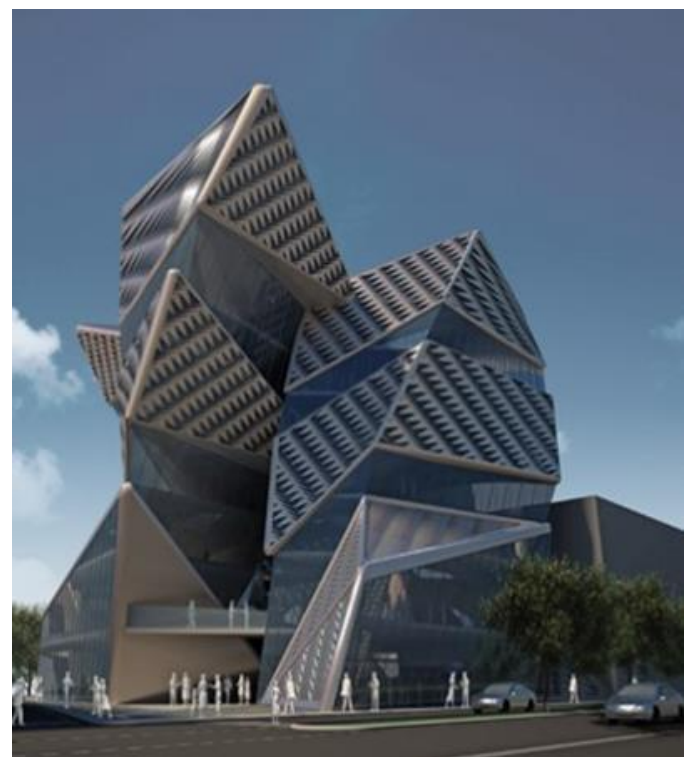

Рисунок 5 - «Benetton GroupHeadquarters».

В качестве примера архитектуры «мегаструктурализма» можно привести проект «Tehran Tower» (рис. 4) от иранских архитекторов Махди Камбоозия, Алиреза Эсфандиари, Нима Дехгхари, Мухаммеда Ашкбара Сефата. Общая форма башни вдохновлена «мукарнасом», т.е. традиционный складчатый или иначе сотовый свод, декорированный нишами-мукарнами, расположенными ярусами в определенной последовательности. Как и в своде, жилые структуры «нависают» уступчатой массой ярусов над городом, опираясь на две мощные опоры. Пространство в основании каждой опоры будет использоваться под автопарковки. Наверху конструкции расположится парк для прогулок и отдыха, предусматривающий зеленые газоны, деревья, кустарники и т.п. На кровле нависающих кубиков так же предусматривается организовать зеленые насаждения и зоны отдыха, причем тонкие, конструктивные элементы играют роль солнцезащитных устройств. Другой пример, проект многоцелевого комплекса для «Benetton Group Headquarters» от студии «AquiliAlberg» (рис. 5). Центральная идея образования впечатляющей структурной формы заключается в интегрированном преобразовании трех одинаковых объемов путем кинетического вращения в единое целое.

Несколько конкурсных проектов выставочного комплекса в Астане, выполнены в виде масштабных структур, деформированных под воздействием сил кручения. Один из них проект австралийской архитектурной фирмь «Kann Finch», возглавляемой Александером Бачимовым, в котором центральный павильон-

ISPC Innovations in science, 
символ выполнен в виде крученого небоскреба, с «висячими садами» по граням извивающихся полос. Это движение как бы продолжается в окружающих его административных и выставочных павильонах, в целом представляя планировочную композицию в виде широкого распластанного цветка. Знаковый объект «Сердие Acmaны»» в виде перекрученного тора или петли Мебиуса высотой 165 м, по которому непрерывно движется обзорный лифт, предложил Сакен Нарынов. По замыслу автора в огромном сооружении должен был распологаться музей Астаны. В единственном казахском проекте
«Солнечный парус» (рис.6), вошедшим в десятку лучших (выполненен проектной академией «Казгор» под руководством Айдара Татыгулова), форма главного здания-символа, высотой 192 м напоминает своеобразный парус в степи, который структурно оборачивается вокруг «мачты». Поверхность здания покрыта гелиобатареями аккумулирующими солнечную энергию - это гелиостанция, выполняющая одновременно функцию выставочного павильона. После выставки в здании может разместиться институт по изучению Солнца - крупный международный научно-исследовательский центр.
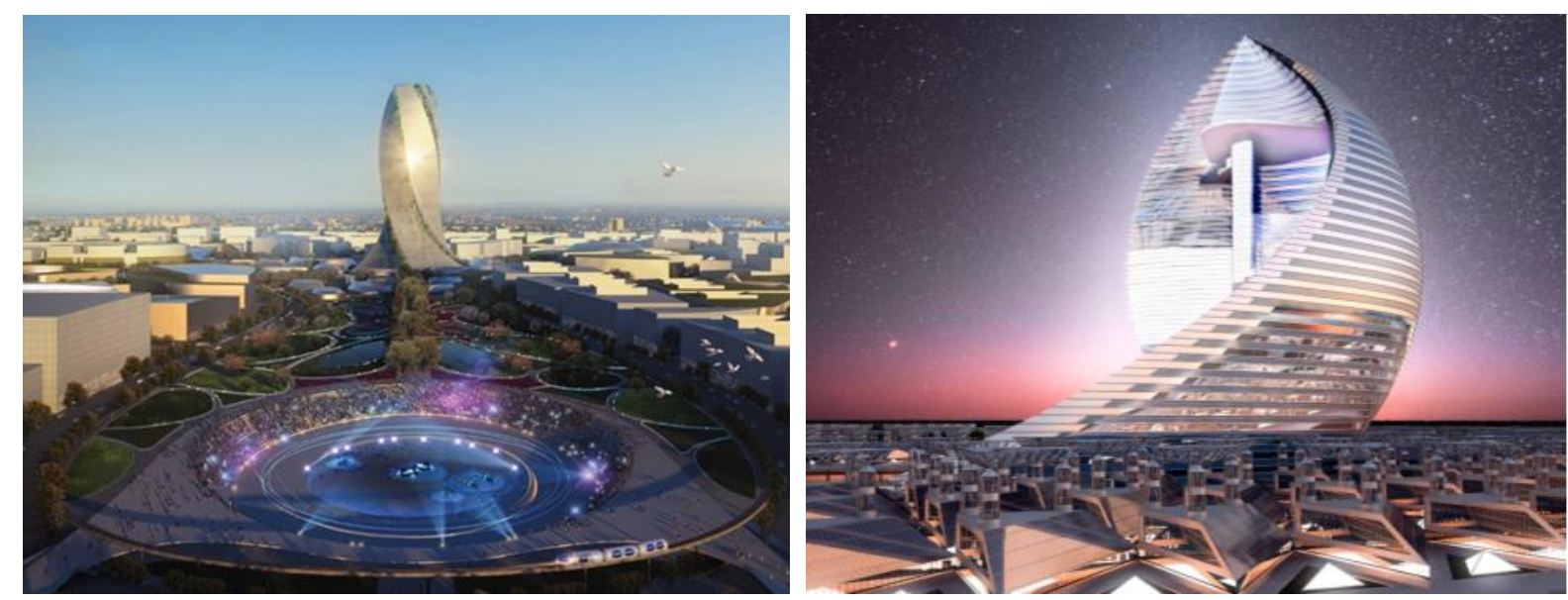

Рисунок 6 - Астана. ЭКСПО-17. Павильон Казахстана «Солнечный парус»,

Режим доступа: http://yvision.kz/post/370009

Концепция кибертектуры создает разумное пространство, используя сочетание интеллектуальных технологий и интерактивного взаимодействия внешних и внутренних факторов, облекая его в футуристические архитектурные формы и смелые инженерные решения [7]. Архитекторы из английской студии «ecoLogicStudio» предложили в рамках этой концепции, проект «Algae Urban Farm» для регионов Ирана. Авторы применили метод параметрического и ассоциативного моделирования здания. Этот метод предусматривает различные манипулирования со структурой, включая изменения, как внешней формы, так и внутренней планировочной организации. Модель реагирует на колебания микроклимата и изменение функциональных требований.

Архитектурная компания «Adrian Smith+Gordon Gill Architecture», выигравшая конкурс на разработку комплекса «ЭКСПО 17» предложила проект, сочетающий инновационные технологии, использование альтернативных видов энергии и интерактивного взаимодействия. Общая площадь территории 173,4 га, 25 гектар которой занимает выставочный комплекс, а остальные 148 га - жилые дома, объекты социально-культурного назначения, парки и т.п. В центре располагается огромный сферический павильон Казахстана - будущий новый символ Астаны, диаметром 150 м, символизирующий биосферу. Вокруг него располагаются выставочные пространства: Международный павильон, перекрывающий пространство почти в 10 га, в нем будут представлены участники более чем из ста стран. Четыре тематических павильона, каждый из которых отражает тематику выставки - «Мир энергии», «Энергия для всех», «Энергия для жизни», «Моя энергия будущего». Кроме них вокруг сферы располагается центр театрального искусства с многофункциональным, трансформирующимся пространством, а также крупный конгресс-центр для проведения конференций и симпозиумов. Плавные, округлые формы зданий способствуют уменьшению энергетических потребностей, а их покрытие и поверхность являясь своеобразной «преобразующей кожей» действует как «электрические станции», используя энергию солнца и ветра. В планировочной композиции комплекса учитывались климатические условия, благоприятная ориентация, а также снеговые и ветровые нагрузки, исходя из которых, разработаны энергосберегающие стратегии. 
Проект предусматривает дальнейшие использование павильонов после окончания выставки, все они могут легко конвертироваться под другие функции - научно-исследовательские, офисные, образовательные и т.п. Все объекты комплекса как в биосфере будут взаимосвязаны и каждый из них, включая жилые здания, будет самодостаточен. Это будет первый в Астане автономный район, полностью обеспечивающий себя энергией, для этого по всему его периметру, а также перед центральным павильоном, образуя своеобразный вход со стороны оси, направленной на Байтерек, будут установлены ветряные турбины, генерирующие энергию.

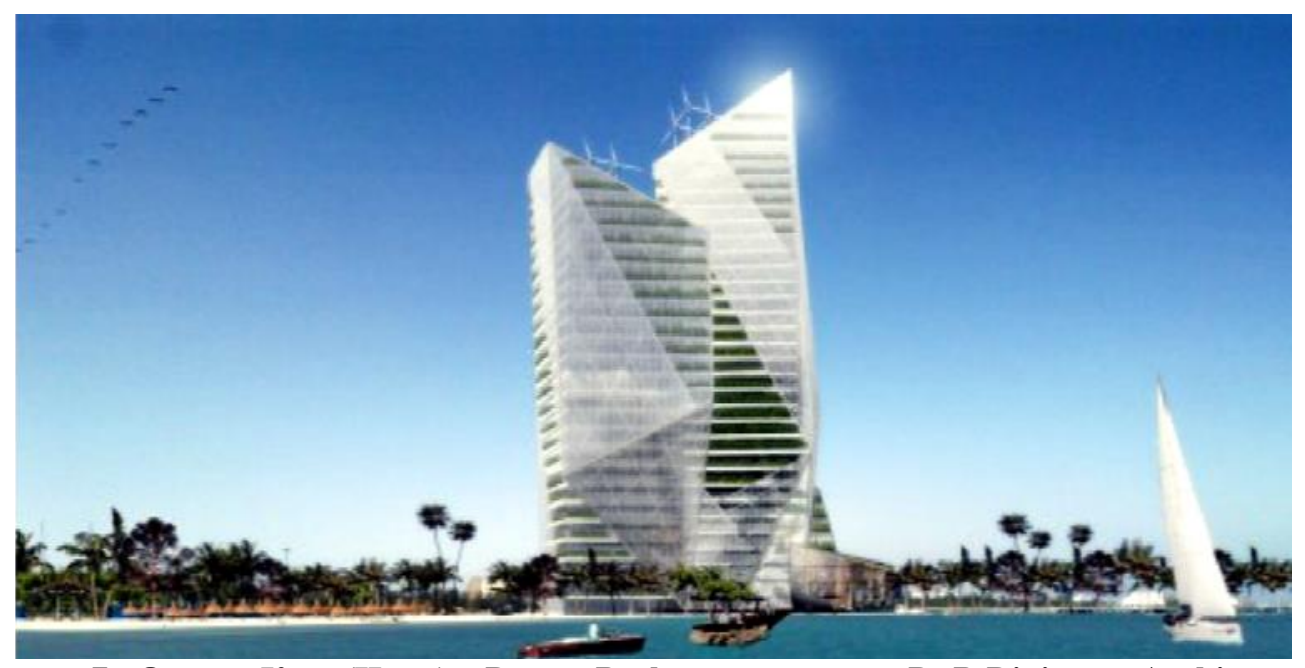

Рисунок 7 - Остров Киш (Иран). «Dream Park», apx. студия «D+R Dipiuerre Architettura».

Концепция тотальной бионики активно применяет энергосберегающие ресурсы и возобновляемые источники энергии, новейшие технологий и строительные материалы, природные элементы (деревья, кустарники и т.п.), а также сборные секции, легко монтирующиеся на строительной площадке. В качестве одного из примеров можно привести архитектуру Центрального кониертного зала «Казахстан», спроектированного Манфреди Николетти. Еще одним убедительным примером является проект многофункиионального комплекса «Premier City» предложенный основателем «тотальной бионики» Кеном Янгом для Алматы [8]. Этот комплекс будет самым зеленым районом в Казахстане. Приватные и парящие сады комплекса соединяют его развитие по горизонтали, в то время как зеленые скаты обеспечивают вертикальную связь между более низкой землей (снижение) и высокими башнями. Внутренние сады жилых башен, поднятые на высокий, небесный уровень позволяют получать круглогодичное удовольствие от флоры, зеленая крыша используется также как палуба наблюдения. «Висячие сады» на крыше высотных башен предлагают также проекты других многофункциональных комплексов Алматы. Проект жилого комплекса для военных «Courtesy of Hootanpei» в Тегеране (Иран), разработанный архитектурной студией «Hootanpei architects» занял первое место в международном конкурсе. Каждое из высотных зданий комплекса расположено на своеобразной платформе, образованной большем по площади основанием пятиэтажного здании. На кровле пятиэтажных домов-платформ, разбит зеленый парк [9]. Проект высотного зеленого оазиса «Dream Park» на острове Киш (рис. 7) предлагает архитектурное бюро «D+R Dipiuerre Architettura». Архитектура двух башен динамически изменяется при рассматривании их с различных ракурсов. Все изгибы вызваны, во-первых, желанием открыть прекрасный вид на острова из всех помещений зданий, во-вторых, башни символизируют Киш их формы повторяют дуновение ветра, отражают море и наполнены цветущими зелеными садами. 

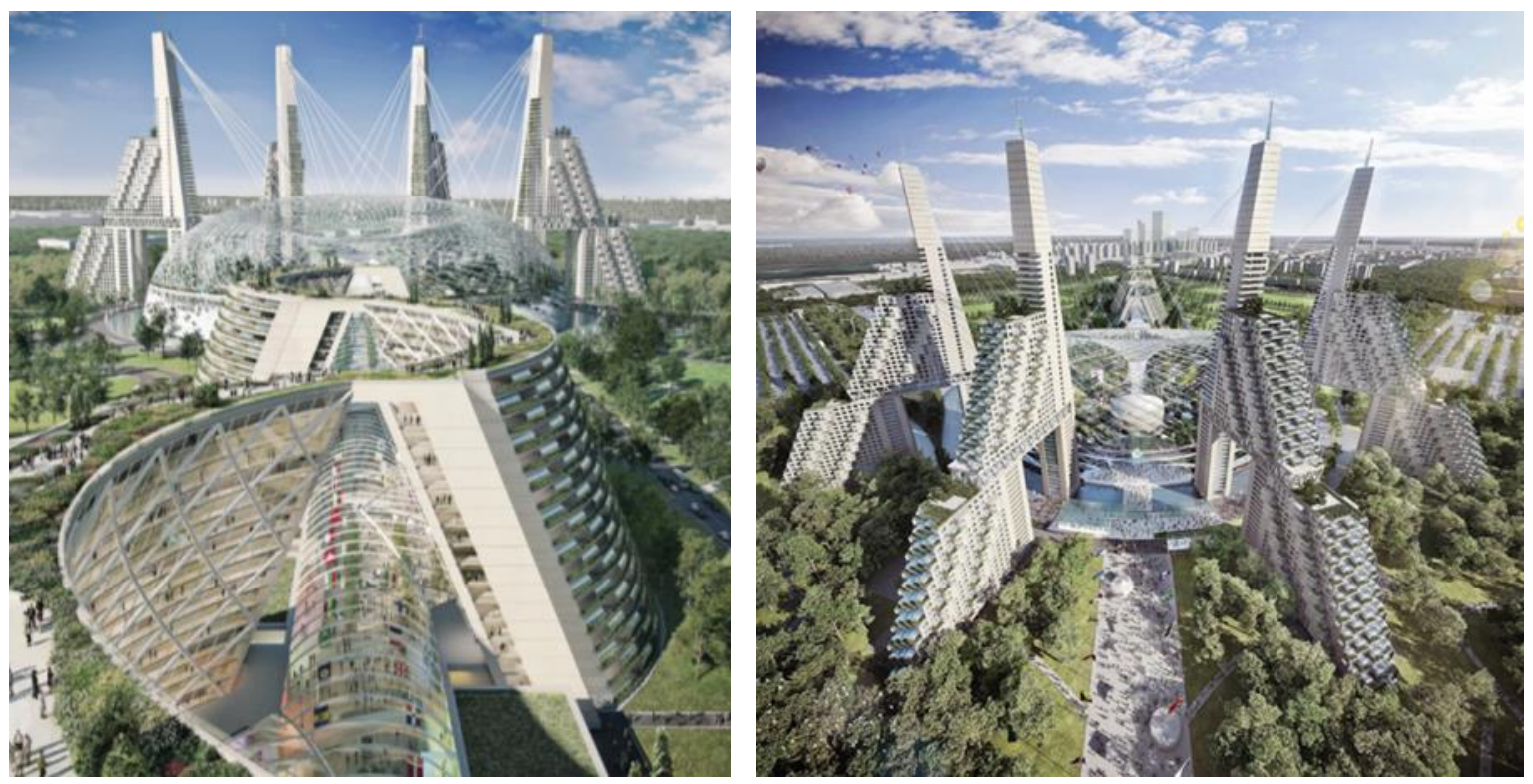

Рисунок 8 - Астана (Казахстан). Проект ЭКСПО-17, архитектор М. Сафди.

Режим доступа: http://yvision.kz/post/370009

Американский архитектор израильского происхождения Моше Сафди представил проект, утверждающий принципы тотальной бионики, на конкурс «ЭКСПО-17» в Астане рис.8). Очень эффектное решение организации пространства выставочного комплекса, учитывающего суровые климатические условия города, поэтому все выставочное пространство комплекса и широкая галерея, ведущая к нему, превращается в огромный сад, обернутый сетчатой структурой. Перекрытие центральной части цилиндрического объема глубокой воронкой прогибается вовнутрь, изливаясь водопадом. Выстовочные пространства расположены внутри зеленых террасных холмов, фланкирующих с двух сторон центральную площадь. Зелень является основной составляющей проекта, она проникает и окутывает все элементы комплекса. Для этого максимально освобождается территория, помещения жилого, офисного и социальнокультурного назначения размещены в четырех ступенчатых башнях, взметнувшиеся «мачты», которых располагаются позади комплекса, а также в извивающемся по центральной оси объеме, направленном на Байтерек. Сводчатый стеклянный тоннель, ведущий к выставке, пронизывает, через треугольные структурные арки, змеевидное сооружение. На его эксплуатируемой кровле разбит зеленый бульвар, ведущий на верхние уровни комплекса и представляющий прекрасный обзор окрестностей. Явным недостатком этого проекта является компиляция из других ранних работ мастера, уже воплощающихся в других частях мира. Например, в городе Циньхуандао (Китай) будет построен жилой комплекс «Golden Dream Вау». Он выполнен в виде ступенчатых объемов, расположенных со смещением один на другим, образовавшийся структурный проем, позволяет осуществлять визуальную связь с окружающей средой. Уступчатые фасады позволяют М. Сафди предусмотреть множество зеленых террас, включающих сады, бассейны, павильоны и другие зоны отдыха. Точно такие же объемы были использованы в проекте ЭКСПО-17.

\section{Заключение}

Исходя из вышесказанного, можно сделать вывод, что в начале XXI века, новейшие технологии определяют сущность содержания и уровень нашей жизни. В то же время идет качественное переосмысление результатов технической революции в архитектуре авангарда. В технологическом плане происходит не заимствование, а специальная разработка техники на самом высоком уровне вплоть до использования космических технологий. Новаторские идеи Запада, как видно из приведенных примеров, находят полномасштабный отклик в проектных разработках Ирана и Казахстана. Этому, прежде всего, способствуют проводимые международные конкурсы, в которых принимают участие прославленные мировые «звезды архитектуры». 


\begin{tabular}{l|lrl|l|ll} 
& ISRA (India) & $=\mathbf{1 . 3 4 4}$ & SIS (USA) & $=\mathbf{0 . 9 1 2}$ & ICV (Poland) & $=\mathbf{6 . 6 3 0}$ \\
Impact Factor: & ISI (Dubai, UAE) $=\mathbf{0 . 8 2 9}$ & PUHL (Russia) $=\mathbf{0 . 2 0 7}$ & PIF (India) & $=\mathbf{1 . 9 4 0}$ \\
& GIF (Australia) & $\mathbf{0 . 5 6 4}$ & ESJI (KZ) & $=\mathbf{3 . 8 6 0}$ & IBI (India) & $=\mathbf{4 . 2 6 0}$ \\
& JIF & $\mathbf{1 . 5 0 0}$ & SJIF (Morocco) & $=\mathbf{2 . 0 3 1}$ & & \\
\hline
\end{tabular}

\section{References:}

1. Leyzerovich A. (2004) Marka Fullera [Tekst] / A. Leyzerovich // Znanie-sila, 2004. N 12. - p. 44-50.

2. Cook P. (1999) Archigram (Group) [Text]/ P. Cook. - New York: Princeton Architectural Press, 1999. - 44 p.

3. Chernihov Ya. (1933) Arhitekturnyie fantazii [Tekst]/ Ya. Chernihov. - Leningrad, 1933. $203 \mathrm{p}$.

4. Vyituleva K.O. (2010) Prostranstvennyie eksperimentyi $\mathrm{V}$ noveyshey arhitekture. (K voprosu o «novyih obrazah») [Tekst]: dis.... kand. iskusstvovedeniya: 17.00.04 / K. O. Vyituleva. - M., 2010. - 243 p.

5. Volichenko O.V. (2013) Vliyanie meynstrimov zapadnogo avangarda $\mathrm{v}$ arhitekture Tsentralnoy Azii [Elektronnyiy resurs] / O. V. Volichenko //Arhitekton: izvestiya vuzov. - 2013. - \# 41. Available: $\quad$ http://archvuz.ru/2013_1/3 (Accessed: 10.09.2017).
6. Balmond C. (2007) Element. Prestel Verlag [Text]/ Cecil Balmond. - New York, 2007. $249 \mathrm{p}$.

7. Pavlikova A. (2008) Kibertekturnyie eksperimentyi ot Dzheymsa Lou [Tekst] / A. Pavlikova. //Vyisotnyie zdaniya. \# 4. M., 2008. - p. 72.

8. Yeang K. (2006) Ecodesign: a manual for ecological design / K.Yeang. - GB : WileyAcademy, 2006. - 499 p.

9. Omuraliev D. (2013) Meynstrimyi noveyshey arhitekturyi - dvadtsat pervyiy vek [Tekst] / D. D. Omuraliev, O. V. Volichenko. Saarbrücken: Palmarium Academic Publishing, 2013. - 449 p.

10. Volichenko O. (2013) Tvorcheskie kontseptsii noveyshey arhitekturyi [Tekst] / O. Volichenko. - Bishkek: ITs "Teknik”, 2013. - 310 p. 